Article

\title{
Soil Carbon Change Due to Land Conversion to Grassland in a Semi-Arid Environment
}

\author{
Gayatri Yellajosula $^{1}$, Larry Cihacek ${ }^{1, *}{ }^{\text {, Tim Faller }}{ }^{2}$ and Christopher Schauer ${ }^{2}$ \\ 1 Soil Science Department, School of Natural Resource Sciences, North Dakota State University, \\ Fargo, ND 58108, USA; gayatri786@gmail.com \\ 2 Hettinger Research Extension Center, North Dakota State University, Hettinger, ND 58639, USA; \\ timothy.faller@ndsu.edu (T.F.); christopher.schauer@ndsu.edu (C.S.) \\ * Correspondence: larry.cihacek@ndsu.edu; Tel.: +1-701-231-8572
}

Received: 24 June 2020; Accepted: 9 July 2020; Published: 16 July 2020

check for updates

\begin{abstract}
A 5-year study evaluated the change in the quantity of soil total C (STC), soil organic C (SOC), and soil inorganic $C$ (SIC) stored in the surface $60 \mathrm{~cm}$ of the soil profile on two adjacent blocks of land with a long-term history of cropping $(\mathrm{CH})$ or undisturbed grassland $(\mathrm{NH})$ on similar soil types between 1999 and 2004. The NH area was tilled and a grass-legume species mix was seeded into plots on both the $\mathrm{NH}$ and the $\mathrm{CH}$ areas. Selected plots of restored grass were established so they could be grazed (GG) by livestock while other plots were left ungrazed (UG). Original undisturbed (and ungrazed) grassland plots within the $\mathrm{NH}$ area were used as a control treatment. Initially, STC and SOC in CH were lower than $\mathrm{NH}$ when compared under the semi-arid environmental conditions found in southwestern North Dakota. Over the study period, the undisturbed grass control plots had increases in STC and SOC levels in the soil profile of $3.90 \mathrm{~kg} \cdot \mathrm{m}^{-2}$ and $3.34 \mathrm{~kg} \cdot \mathrm{m}^{-2}$, respectively. Restored grass on the $\mathrm{NH}$ area with grazing showed increases in STC and SOC values of 2.11 and $1.26 \mathrm{~kg} \cdot \mathrm{m}^{-2}$, respectively, while without grazing, profile STC and SOC had values of 3.80 and $3.28 \mathrm{~kg} \cdot \mathrm{m}^{-2}$, respectively. Restored grass on the $\mathrm{CH}$ area showed increases in profile STC and SOC values of 0.55 and $1.96 \mathrm{~kg} \cdot \mathrm{m}^{-2}$, respectively, for the grazed plots and 0.78 and $2.11 \mathrm{~kg} \cdot \mathrm{m}^{-2}$, respectively, when left ungrazed. Soil inorganic $\mathrm{C}$, though present in the soils, did not significantly change during the study. The lower $\mathrm{C}$ accumulation in the $\mathrm{CH}$ plots may be due to a lag time in the establishment of mycorrhizal associations with the seeded species, the inoculums of which were already present in the NH soils. Changes in STC were likely due to changes in water relationships in the soil profile where management changes affected water infiltration and its movement causing leaching of SIC below the $60 \mathrm{~cm}$ depth evaluated. Soils under undisturbed grassland continue to accumulate carbon while soils of the disturbed grassland or cropped prior to re-establishing grass showed losses that occurred due to either accumulating $C$ at a lower rate or perhaps to $C$ loss during the initial establishment period (1-2 years).
\end{abstract}

Keywords: soil carbon; grassland restoration; cropped land history; grassland history; soil organic carbon; soil inorganic carbon; soil total carbon

\section{Introduction}

Recent interest in utilizing agricultural lands for sequestering carbon dioxide $\left(\mathrm{CO}_{2}\right)$ as a strategy to mitigate global climate change has resulted in a wide range of research activities [1]. One strategy is to convert cropland into grassland to enhance soil carbon (C) sequestration especially on lands that are marginal for crop production or have been degraded by long-term cropping. Many of these areas occur in the Great Plains of North America where the original vegetation was a prairie grassland. Cultivation by European settlers resulted in a loss of 20 to 60 percent of the original soil organic matter (SOM) in prairie soils over the past century [2]. 
Conversion of land from its native state, usually grassland or forest, to agricultural use, results in soil $\mathrm{C}$ loss through SOM oxidation enhanced by tillage [3,4]. In addition, it has been estimated that the conversion of native prairies to cropland has contributed nearly $1 / 3$ of the net $\mathrm{CO}_{2}$ emissions to the atmosphere [5]. Conversion of croplands to grasslands can reverse this loss when the grasslands are properly managed [6].

In semi-arid areas of the Great Plains, agricultural production can be erratic due to high variability in precipitation. Over time this resulted in the development and adaptation of a small grain crop-fallow culture to optimize water capture and nutrient accumulation to stabilize crop yields. This culture consists of alternating years of seeded crops in the first year and allowing the land to remain unplanted (fallow) in the second year. During the fallow year, the land is cultivated several times to control weed growth to minimize water loss by evapotranspiration through plants. The tillage also hastens the decomposition of plant residues and soil organic matter resulting in increasing available soil nutrients.

Cihacek and Ulmer [2] examined C cycling in the surface $15 \mathrm{~cm}$ of the soil nearby in a semi-arid region of the northern U.S. Great Plains under adjacent areas of undisturbed native grassland and long-term crop-fallow cultivation on the same soils. They found that soil organic carbon (SOC) or soil organic matter (SOM) in the cropland had declined since the beginning of cultivation but estimated that current SOC levels remained relatively constant. However, fallowed soils have little or no plant residue cover and are susceptible to wind and water erosion that can also result in SOC or soil organic matter (SOM) losses.

Other studies have also shown that conversion of grassland to cropland results in loss of SOC due to soil tillage. During tillage, the soil is disturbed and the growth of grassroots is disrupted which results in less below soil surface root biomass production. Liebig et al. [7] evaluated contemporary research and reported average losses of $34 \pm 14 \%(12.1 \pm 7.9 \mathrm{~g} \mathrm{C} / \mathrm{kg}$ soil $)$ of SOC upon conversion of grassland to cropping. Others have also attempted to estimate $C$ losses and have noted similar results [8-10]. Soil C loss depends on the climate, soil texture, soil disturbance, and erosion. On the other hand, [7] also noted that the conversion of cropland to grass increased SOC by up to $0.94 \pm 0.86$ $\mathrm{Mg} \mathrm{C} \cdot \mathrm{ha}^{-1} \cdot \mathrm{yr}^{-1}$. However, some studies have shown SOC and SIC accumulating deeper in the soil profile in cropland [11-13].

About 336 million ha of grazing lands exist in the U.S., of which undisturbed grasslands make up about $48 \%$ [14]. The remainder of the total grazing lands is temporary pasture. Schuman et al. [14] estimated that, with proper management of grazing of rangelands, stored $C$ can increase from 0.1 to $0.3 \mathrm{Mg} C \cdot \mathrm{ha}^{-1}$ per year. However, native rangelands can be a significant $\mathrm{C}$ source or sink because they cover a vast land area [14].

Under existing management conditions, most temperate grasslands worldwide are considered to be $C$ sinks. In the USA and Canada, Bruce et al. [15] estimated that soils sequester, on an average, $0.2 \mathrm{Mg} \mathrm{C} \cdot \mathrm{ha}^{-1} \cdot \mathrm{yr}^{-1}$, while Conant et al. [16] produced an estimate of $0.58 \mathrm{MgC} \cdot \mathrm{ha}^{-1} \cdot \mathrm{yr}^{-1}$ for the same region. Soil $\mathrm{C}$ accumulation is strongly influenced by the productivity of the grassland systems and the range of observations is large. Soil organic $C$ sequestration potential for rangelands is highly variable due to the diversity of plant communities, soils and landscapes, and environmental conditions [7,17]. Soil organic carbon increased by $0.16 \pm 0.12 \mathrm{MgC} \cdot \mathrm{ha}^{-1} \cdot \mathrm{yr}^{-1}$ in grazed grassland soils and converting cropland to rangeland increased soil C by $0.94 \pm 0.86 \mathrm{Mg} \mathrm{C}^{-1} \mathrm{ha}^{-1} \cdot \mathrm{yr}^{-1}$ [7]. Gebhart et al. [18] reported that the most productive area of the US Central Plains region accumulated $1.1 \mathrm{Mg} \mathrm{C} \cdot \mathrm{ha}^{-1} \cdot \mathrm{yr}^{-1}$ while under more arid conditions, Burke et al. [19] reported that the short grass steppe of Colorado accumulated only $0.03 \mathrm{Mg} \mathrm{C} \cdot \mathrm{ha}^{-1} \cdot \mathrm{yr}^{-1}$ over a period of 50 years.

Most research focuses on soil organic $C$ changes in soils. However, soil inorganic carbon (SIC) is an important component of many arid and semi-arid rangelands soils, but only recently has received attention as a C storage pool [20]. Total soil carbon is the sum of the SOC and SIC and represents the entire $C$ stored in soils. In addition, numerous studies have often reported soil $C$ concentration rather than mass which decreases the utility of the data for estimating soil $\mathrm{C}$ reserves and response to changes in the environment or management [21]. There is also some evidence that grazing management may 
be affecting SIC more than SOC [22]. Cihacek and Ulmer [12] and Mikhailova and Post [23] have noted that significant quantities of soil IC can accumulate in soils under cultivation in environments that are favorable for SIC precipitation. Thus, although rarely reported, soil TC may be a better reflection of all of the changes in soil C than just reporting SOC, especially where climatic conditions favor SIC accumulation.

This study was conducted to determine the capacity of soils to accumulate $C$ under semi-arid grass production systems through; (i) determining $\mathrm{C}$ accumulation occurring in soils converted from long-term native grassland to improved grassland; (ii) determining $C$ accumulation of soils converted from long term cropland to grassland; (iii) evaluating the effects of grazing management on these restored grasslands; and (iv) noting distribution of accumulated C between SOC, SIC, and STC. This research will also provide information related to changes in SOC associated with depth in the soil profile.

\section{Materials and Methods}

\subsection{Experimental Site}

The North Dakota State University (NDSU) Hettinger Research Extension Center (HREC) is located approximately $543 \mathrm{~km}$ west of Fargo, North Dakota. The study area was located $1 \mathrm{~km}$ west of Hettinger, North Dakota at $45^{\circ} 57^{\prime} 38^{\prime \prime} \mathrm{N}$ and $102^{\circ} 22^{\prime} 10^{\prime \prime} \mathrm{W}$ with an elevation of $781.5 \mathrm{~m}$ above mean sea level. The average annual temperature is $6{ }^{\circ} \mathrm{C}$ and the 30 -year average annual rainfall is $335 \mathrm{~mm}$ at this location [24]. The HREC is located in Major Land Resource Area (MLRA) 54, the Rolling Soft Shale Plain, part of Land Resource Region F (Northern Great Plains Spring Wheat Region) [25]. The climate is semi-arid with an average rainfall of $414 \mathrm{~mm}$ across the MLRA. Two different but similar soil series are found at the location of the study site both formed on a geologically old (and unglaciated) stream terrace.

The Bowdle (fine-loamy over sandy or sandy-skeletal, mixed, superactive, frigid pachic Haplustolls) series consist of moderately deep well-drained soils formed in loamy alluvium underlain by sand and gravel [26]. The permeability is moderate throughout the solum. Slopes of the Bowdle soils range from 0 to $15 \%$ with a slope of less than $2 \%$ at the study site. The mean annual air temperature is $6.6{ }^{\circ} \mathrm{C}$ and the mean annual precipitation is $457 \mathrm{~mm}$ for a typical Bowdle site. The Bowdle soil at the study site was a sandy loam ( $60 \%$ sand, $26 \%$ silt, $14 \%$ clay).

The Ruso (coarse-loamy, mixed, superactive, frigid pachic Haplustolls) series consist of very deep well-drained soils [27]. These soils formed in loamy alluvium over sand and gravel. Permeability is moderately rapid in the upper part of the profile and very rapid in the substratum. Slopes of the Ruso soils range from 0 to $9 \%$ with a slope of less than $2 \%$ at the study site. The mean annual temperature is $4.4{ }^{\circ} \mathrm{C}$ and the mean annual precipitation is $406 \mathrm{~mm}$ (16 inches) for a typical Ruso site. The texture of the Ruso soil at the study site was a sandy loam ( $60 \%$ sand, $26 \%$ silt, $14 \%$ clay) very similar to the Bowdle soil.

The native grassland history area consisted of approximately $60 \%$ Ruso soils and $40 \%$ Bowdle soils while the cropped history area had approximately $60 \%$ Bowdle soils and $40 \%$ Ruso soils. With the very similar textural characteristics of the two soils as well as similar depths over gravel, no distinction was made between the two areas when the treatments were laid out.

In 1999, plots were established with collaboration between the NDSU Animal and Range Science, Agricultural Economics and Agri-Business, and the Soil Science Departments. An undisturbed native grassland site $(\mathrm{NH})$ with a history of never having been tilled and a site with a long-term cropped history $(\mathrm{CH})$ (>70 years of tillage) were identified to examine the feasibility for farmers and ranchers to either (a) convert rangeland to cropland, (b) convert cropland to rangeland and within these options to (c) graze or (d) not graze the rangeland or to use (e) conventional tillage or (f) no-till for production of small grains including spring wheat (Triticum aestivum L.), barley (Hordeum vulgare L.) and oats (Avena sativa L.) to improve their potential economic security by providing alternative management 
systems within the highly variable climatic conditions in this region. The two areas were located about $200 \mathrm{~m}$ apart. The cropland management portion of the study will not be reported here but has been reported elsewhere [28]. The native grassland area had been moderately grazed ( $50 \%$ biomass removal) for several decades by cattle and sheep up to the time of disturbance. The predominant grass species were blue grama (Bouteloua gracilis (Willd. ex Kunth) Lag. ex Griffiths), side oats grama (Bouteloua curtipendula (Michx.) Torr.), green needlegrass (Nassella viridula (Trin.) Barkworth), occasional crested wheatgrass (Agropyron cristatum (L.) Gaertn), threadleaf sedge (Carex filifolia Nutt.), unidentified forbes, and occasional prickly pear cactus (Opuntia humifusa (Raf.) Raf.). Crested wheatgrass in the undisturbed grassland appeared to have invaded the grassland from other pastures in the general area of the plots. The major species seeded in the restored grass plots was crested wheatgrass and alfalfa (Medicago sativa L.). The grazing management was either with grazing (GG) or without grazing (UG) for both the restored $\mathrm{CH}$ and $\mathrm{NH}$ areas.

When the restored grassland plots were established in 1999, 6 plots were laid out in the area that was previously under long-term crop production $(\mathrm{CH})$, while 6 plots were established in the area where the native rangeland $(\mathrm{NH})$ was tilled and seeded with the forage species. Three plots with the original vegetation were left undisturbed in the $\mathrm{NH}$ area as control plots to allow for comparison with treatments on both the $\mathrm{NH}$ and $\mathrm{CH}$ areas. Although the predominant grass species established was crested wheatgrass, during the 2004 sampling, both crested wheatgrass and smooth bromegrass (Bromus inermis Leyss.), as well as alfalfa, were observed in the restored plots. The undisturbed native grass plots and the restored grass plots that remained ungrazed were $3.1 \mathrm{~m}$ by $31 \mathrm{~m}$ long. The grazed plots were $24.6 \mathrm{~m}$ by $31 \mathrm{~m}$, enclosed by a fence, and provided with gate and water source to allow for managed animal grazing with a target of $50 \%$ biomass removal. A completely randomized design with three replications was used within each area.

\subsection{Field Sampling}

The initial sampling in the fall of 1999 was done using a JMC Back Saver (Mention of trade names or brands constitute endorsement neither by authors nor by North Dakota State University but are provided only for the reader's reference.) extendable handle probe with a standard 38-cm long dry soil sampling tube with a 19-mm diameter tip. The cores were taken in two successive $30-\mathrm{cm}$ deep probes and divided up into 0-10, 10-20, 20-30, 30-45, 45-60-cm depth increments, respectively. Three cores from each plot were analyzed for $\mathrm{C}$ by respective depth increments. Since soil bulk density data was not obtained at the initial sampling, bulk density data was collected in 2001 using the core method of Blake and Hartge (1986) from three cores collected from each plot with a truck-mounted hydraulic soil-coring probe. In 2004, bulk density data were collected on the actual cores obtained for C determination.

In early August 2004, four soil cores were collected from each of the plots using a truck-mounted hydraulic soil-coring probe. The cores were spaced in a line approximately $7.5 \mathrm{~m}$ apart. Each core was collected to a depth of $60-\mathrm{cm}$ in a $60-\mathrm{mm}$ diameter steel sampling tube lined with a $57-\mathrm{mm}$ diameter acetate contamination liner. The soils at the study site are underlain by gravel which limits the sampling depth by this method to approximately $60 \mathrm{~cm}$ but also places a lower boundary on the effective plant rooting depth and the soils ability to accumulate $\mathrm{C}$. However infiltrated precipitation can drain out of the soil profile, thereby, carrying labile or soluble $C$ with it allowing for an illustration of the movement of $C$ within a soil system. All cores were numbered from east to west so that information obtained from this sampling could be related to past and future sampling information consistently if necessary. The sampling position of each core was also identified marked for latitude and longitude using a handheld Garmin GPS 76 Global Positioning Satellite (GPS) receiver unit.

Once a soil core was obtained, the core and acetate liner were removed from the steel sampling tube. The acetate liner was trimmed to the length of the soil core, if necessary, capped with plastic caps and sealed with duct-tape to prevent moisture loss. The sealed cores were then transported back to the 
laboratory at North Dakota State University and placed in cold storage until they could be processed for analysis.

\subsection{Soil Sample Processing}

In preparing the cores for analysis, the acetate liners were cut open with a carpet knife. and divided into 0-10, 10-20, 20-30, 30-45, and 45-60-cm depth increments. The core segments were bagged in tared plastic bags, weighed, hand-crushed, mixed, and sub-sampled for moisture content. The remaining portion of each core segment was then air-dried, crushed to pass a 2-mm screen, again mixed and bagged in individual soil sample bags. Bulk density for each core segment was determined from its total mass and moisture content for use in $\mathrm{C}$ mass calculations as described by Blake and Hartge [29].

\subsection{Carbon Measurement}

After the soil samples were processed, sub-samples of 12 to $15 \mathrm{~g}$ of each thoroughly homogenized soil sample were milled in a ball mill with carborundum media to pass a 100-mesh sieve as described by Cihacek and Jacobson [30]. Carbon analysis was performed with a Scalar Primacs ${ }^{\mathrm{TM}}$ solid carbon analyzer. This instrument can perform both total $C$ analysis by high-temperature combustion $(\sim 1000$ $\left.{ }^{\circ} \mathrm{C}\right)$ and inorganic $\mathrm{C}$ analysis from $\mathrm{CO}_{2}$ release by acid addition $\left(20 \% \mathrm{H}_{3} \mathrm{PO}_{4}\right)$. Reaction time was $420 \mathrm{~s}$ to ensure maximum recovery of both total and inorganic $\mathrm{C}$. Organic carbon was obtained by subtracting inorganic carbon from total carbon. Percent $C$ values obtained from the analysis were adjusted for bulk density to calculate soil $C$ mass. All $C$ values are reported as $C$ mass per unit area per soil depth increment $\left(\mathrm{kg} \cdot \mathrm{m}^{-2} \cdot \mathrm{depth}^{-1}\right)$.

\subsection{Statistical Analysis}

The experimental design used for statistical analysis was a completely randomized design (CRD) with three replications and a split-split plot arrangement. The whole plot was previous management history and the first subplot was the type of grass management. The second sub-plot (split) was soil depth. Mean separation was accomplished using the LS means function of the PROC GLM procedure of SAS [31]. This function performs a t-test between each pair of treatment means. Previous management history $(\mathrm{NH}$ and $\mathrm{CH}$ ) was included as a part of the treatments. Significant differences were determined between years, treatments, and soil depths as well as year by treatment, year by depth, and treatment by depth interactions. Soil $\mathrm{C}$ changes are reported as total change as well as annual change (total change $\div 5$ years). Least significant differences (LSDs) for annual change were calculated for those components that showed the significance of $p \leq 0.05$.

\section{Results and Discussion}

The analyses of variance table for changes in SOC, SIC, and STC are shown in Table 1 . The table includes the sources of variation, degrees of freedom, mean squares, and results of F-tests from the combined analyses for the two sampling years. The sources of variation are represented by treatment (A), depth (B), and treatment by depth interaction is represented by (AB). For STC, significant differences were observed between sampling years $(p=0.001)$, treatments $(p=0.05)$, sampling depth increments $(p=0.001)$ and the interaction between treatment and depth $(p=0.01)$. However, only depth increment was the significant variable $(p=0.001)$ for the SIC data. LSD $_{0.05}$ values for treatment or depth are annotated in Tables 2-4.

The SOC data showed significant differences between years $(p=0.001)$, treatments $(p=0.01)$, soil depth increments $(p=0.001)$, and the interaction between treatment and depth $(p=0.01)$. The statistical analyses reflect the changes in soil $\mathrm{C}$ between the initial soil sampling in 1999 and the final soil sampling in 2004 as well as the interactive changes that occurred over the 5-year period between grass and land management treatments and soil profile depth increments. In a semi-arid environment, SIC can 
contribute to STC as shown by Cihacek and Ulmer [12], but the overall picture of $C$ sequestration dynamics in this study was driven by changes in SOC.

\subsection{Soil Organic Carbon}

A comparison of the SOC sequestered in undisturbed grass and restored grass with moderate grazing (GG) (50\% biomass removal) or without grazing (UG) for both the $\mathrm{NH}$ and $\mathrm{CH}$ plot areas is shown in Table 2. The greatest increase in SOC was observed in the undisturbed grassland followed by ungrazed plots (UG) in the long-term grassland (NH area) that had been tilled and restored. Increases in SOC were observed throughout the $60 \mathrm{~cm}$ profile of both treatments. There was a smaller increase for the ungrazed, restored grass in the area with the long-term cropping history $(\mathrm{CH}$ area) at various depths. However, with grazing (GG), the grass on the $\mathrm{CH}$ area plots showed more $\mathrm{C}$ sequestered than on the tilled and restored $\mathrm{NH}$ area. The increases in profile SOC for the ungrazed restored grass plots were $98 \%$ and $63 \%$ of undisturbed grassland for the $\mathrm{NH}$ and $\mathrm{CH}$ areas, respectively. Plots that were grazed showed much lower levels of SOC accumulation than the UG plots. The plots established on the area that was previously native grassland $(\mathrm{NH})$ showed a slight decrease in the GG treatment for OC in the $0-10 \mathrm{~cm}$ depth zone while plots established on the $\mathrm{CH}$ area showed a general increase throughout the profile. The GG plots restored on the NH area sequestered $38 \%$ of the OC that was sequestered by the undisturbed grassland plots (control) while on the $\mathrm{CH}$ area, the GG plots sequestered $59 \%$ of the $\mathrm{C}$ sequestered in the control treatment.

The lower soil $\mathrm{C}$ accumulations in both grass restoration treatments on the $\mathrm{CH}$ area may be due to several factors. First, the original levels in organic $C$ in the surface depth increment $(0-10 \mathrm{~cm})$ are lower due to long-term loss resulting from disturbance by cultivation. The newly established grass may require more than one season to develop a root system that actively contributes measurable amounts of $C$ to the soil $C$ pool. In addition, grass species often require the development of mycorrhizal associations that enhance root growth and vigor [32,33].

Poor mycorrhizal colonization of grassroots is likely in soils under long-term cultivation because crop plant species are not likely to support the mycorrhizal populations that normally infect range plants. A change in plant species mix (crop species to rangeland species) may delay the efficiency of the development of the mycorrhizal associations needed by grass species. The disturbance due to tillage of the native grassland and immediate restoration of the grass would have a smaller impact on the mycorrhizal populations that are grass species-specific due to a residual presence of mycorrhizal inoculum in the $0-10 \mathrm{~cm}$ depth zone while plots established on the $\mathrm{CH}$ area showed a general increase throughout the profile. The GG plots restored on the $\mathrm{NH}$ area sequestered $38 \%$ of the OC of that sequestered the undisturbed grassland $(\mathrm{NH})$ control plots while on the $\mathrm{CH}$ sequestered $59 \%$ of the $\mathrm{C}$ sequestered in the NH control treatment.

Thus, the restored grass can establish mycorrhizal associations on the area of long-term grassland history much more quickly and to be more efficient in sequestering C. Grazing newly established grass on both native grassland that is disturbed and restored to grass (NHGG) and long-term cropland restored to grass (CHGG) reduces the efficiency of the grass sequestering $\mathrm{C}$ due to the stress imposed on the grass plants by grazing. It has been previously reported that continuous grazing results in constant root elongation and production of root biomass $[4,34,35]$. The data shown here indicate that newly restored grass under the semi-arid conditions of southwestern North Dakota may require a "rest" period during the first one or two growing seasons before it can be subjected to grazing pressure. This would allow for grass root establishment and the development of the mycorrhizal associations essential for healthy grass growth and both vegetative and root biomass production. 
Table 1. Sources of variation, degrees of freedom, mean squares, and results of F-tests from the combined analyses across years for total carbon (STC), inorganic carbon (SIC), and organic carbon (SOC).

\begin{tabular}{|c|c|c|c|c|c|c|c|c|c|c|c|c|c|}
\hline \multirow[b]{2}{*}{ Source of Variation } & \multicolumn{5}{|c|}{ Total Carbon } & \multicolumn{4}{|c|}{ Inorganic Carbon } & \multicolumn{4}{|c|}{ Organic Carbon } \\
\hline & DF & Type III SS & Mean Square & F Value & Pr $>F$ & Type III SS & Mean Square & F Value & $\operatorname{Pr}>\mathrm{F}$ & Type III SS & Mean Square & F Value & $\operatorname{Pr}>\mathrm{F}$ \\
\hline Year & 1 & 8.19 & 8.192 & 18.05 & $<0.0001^{* * *}$ & 0.002 & 0.002 & 0.01 & 0.9091 & 8.82 & 8.82 & 39.1 & $<0.0001^{* * *}$ \\
\hline $\operatorname{trt}(\mathrm{A})$ & 5 & 6.11 & 1.222 & 2.69 & 0.0267 * & 0.360 & 0.072 & 0.49 & 0.783 & 4.94 & 0.987 & 4.37 & $0.0014^{* *}$ \\
\hline Year $\times$ trt & 5 & 4.19 & 0.838 & 1.85 & 0.1132 & 0.843 & 0.169 & 1.14 & 0.3442 & 2.37 & 0.474 & 2.1 & 0.0739 \\
\hline Year $\times \operatorname{trt} \times$ rep Error(a) & 20 & 10.9 & 0.509 & 1.12 & 0.3456 & 3.97 & 0.198 & 1.35 & 0.1755 & 5.03 & 0.251 & 1.11 & 0.3535 \\
\hline depth (B) & 4 & 28.9 & 7.239 & 15.95 & $<0.0001^{* * *}$ & 6.75 & 1.69 & 11.46 & $<0.0001^{* * *}$ & 26.7 & 6.67 & 29.6 & $<0.0001^{* * *}$ \\
\hline Year $\times$ depth & 4 & 1.26 & 0.315 & 0.7 & 0.5976 & 0.231 & 0.058 & 0.39 & 0.8136 & 0.429 & 0.107 & 0.47 & 0.7542 \\
\hline Year $\times$ depth $\times$ rep Error $(b)$ & 16 & 6.03 & 0.377 & 0.83 & 0.6489 & 3.96 & 0.248 & 1.68 & 0.0672 & 3.06 & 0.191 & 0.85 & 0.631 \\
\hline $\operatorname{trt} \times \operatorname{depth}(\mathrm{AB})$ & 20 & 20.6 & 1.031 & 2.27 & 0.0053 ** & 1.96 & 0.098 & 0.67 & 0.8473 & 11.5 & 0.576 & 2.55 & $0.0017^{* *}$ \\
\hline year $\times$ trt $\times$ depth Error $(c)$ & 20 & 6.89 & 0.345 & 0.76 & 0.7525 & 2.94 & 0.147 & 1.00 & 0.4749 & 2.04 & 0.102483 & 0.45 & 0.9762 \\
\hline
\end{tabular}

$* * *$ *** indicate significance at the $p=0.05, p=0.01$ and $p=0.001$ levels, respectively 
Table 2. Effects of management on profile changes in soil organic carbon levels over a five year period for undisturbed native grassland that was tilled and restored to grass and long-term cropland converted to grass.

\begin{tabular}{|c|c|c|c|c|c|c|c|c|}
\hline \multirow[t]{3}{*}{ Depth Increment } & \multicolumn{8}{|c|}{ Grazing Management } \\
\hline & \multicolumn{4}{|c|}{ Ungrazed (UG) } & \multicolumn{4}{|c|}{ Grazed (GG) } \\
\hline & 1999 & 2004 & $\begin{array}{c}\text { Total } \\
\text { Change }\end{array}$ & $\begin{array}{l}\text { Annual } \\
\text { Change }\end{array}$ & 1999 & 2004 & $\begin{array}{c}\text { Total } \\
\text { Change }\end{array}$ & $\begin{array}{l}\text { Annual } \\
\text { Change }\end{array}$ \\
\hline \multirow[t]{2}{*}{$\mathbf{c m}$} & \multicolumn{4}{|c|}{$\mathrm{kg} \cdot \mathrm{m}^{-2}$} & \multicolumn{4}{|c|}{$\mathrm{kg} \cdot \mathrm{m}^{-2}$} \\
\hline & \multicolumn{8}{|c|}{ Undisturbed native grassland (NH Control) } \\
\hline $0-10$ & 2.28 & 3.09 & 0.80 & 0.16 & & & & \\
\hline $10-20$ & 1.55 & 1.86 & 0.31 & 0.06 & & & & \\
\hline $20-30$ & 1.04 & 1.41 & 0.37 & 0.07 & & & & \\
\hline $30-45$ & 1.32 & 2.18 & 0.86 & 0.17 & & & & \\
\hline $45-60$ & 1.51 & 2.50 & 0.99 & 0.20 & & & & \\
\hline \multirow[t]{2}{*}{ Total } & 7.70 & 11.04 & 3.34 & 0.67 & & & & \\
\hline & \multicolumn{8}{|c|}{ Undisturbed native grassland with tillage and restoration to grass $(\mathrm{NH})$} \\
\hline $0-10$ & $2 . \overline{43}$ & 2.85 & 0.41 & 0.08 & 2.81 & 2.83 & 0.02 & 0.00 \\
\hline $10-20$ & 1.29 & 2.06 & 0.77 & 0.15 & 1.35 & 1.72 & 0.36 & 0.07 \\
\hline $20-30$ & 0.96 & 1.35 & 0.39 & 0.08 & 1.15 & 1.22 & 0.07 & 0.01 \\
\hline $30-45$ & 1.10 & 2.00 & 0.90 & 0.18 & 1.52 & 1.84 & 0.33 & 0.07 \\
\hline $45-60$ & 0.96 & 1.76 & 0.80 & 0.16 & 1.34 & 1.82 & 0.48 & 0.10 \\
\hline \multirow[t]{2}{*}{ Total } & 6.74 & 10.01 & 3.28 & 0.66 & 8.17 & 9.43 & 1.26 & 0.25 \\
\hline & \multicolumn{8}{|c|}{ Cropland restored to grassland $(\mathrm{CH})$} \\
\hline 0-10 & 1.56 & 1.77 & 0.21 & 0.04 & 1.53 & 1.91 & 0.38 & 0.08 \\
\hline $10-20$ & 1.23 & 1.76 & 0.52 & 0.10 & 1.44 & 1.77 & 0.32 & 0.06 \\
\hline $20-30$ & 0.99 & 1.33 & 0.33 & 0.07 & 0.88 & 1.21 & 0.33 & 0.07 \\
\hline $30-45$ & 1.42 & 1.71 & 0.28 & 0.06 & 1.66 & 1.96 & 0.30 & 0.06 \\
\hline $45-60$ & 1.75 & 2.51 & 0.76 & 0.15 & 1.48 & 2.11 & 0.63 & 0.13 \\
\hline Total & 6.96 & 9.07 & 2.11 & 0.42 & 6.99 & 8.95 & 1.96 & 0.39 \\
\hline
\end{tabular}

\subsection{Soil Inorganic Carbon}

Changes in soil inorganic carbon (SIC) due to the grass restoration and management treatments are shown in Table 3. Little work has been done on impacts of soil management on SIC and additional research is needed on this soil carbon component to evaluate its role in total soil $\mathrm{C}$ sequestration. However limited recent research has shown that under certain conditions IC may also accumulate as sequestered $C$ in the soil $[20,21]$.

A decrease in inorganic $C$ was observed in the UG treatment in the long-term cropland history plots in the 45-60 cm depth zone. Grassland that had been disturbed and restored to grass $(\mathrm{NH})$ showed $95 \%$ and $151 \%$ of the SIC accumulation of the undisturbed grass for no-grazing or grazing management, respectively. On the other hand, when the $\mathrm{CH}$ area was restored to grass without grazing, a net loss of SIC was observed. The decrease of the inorganic carbon may be due to the dissolution of inherent carbonate minerals and transported to be deposited deeper in the profile as secondary carbonates. The zone of SIC loss is just above the gravel layer found in these soils and the carbonates may have been transported into this layer. The movement of IC out of the cropland restored to grass with grazing may be due to improved water infiltration with improved soil structure resulting from soil proliferation by grassroots. It should be noted that Cihacek and Ulmer [12] have previously reported SIC accumulation in the soils of MLRA 54.

Soils under long-term cropping usually have a poor structure [23] due to the destruction of soil aggregates by tillage and soil organic matter destruction. Restoration of soil structure increases water infiltration. However, with grazing, hoof action by animals may reduce or maintain poor soil structure 
reducing water infiltration. This is illustrated by the greater loss of SIC from the UG plots than from the GG plots with fate if the SIC likely being the movement into the underlying sand and gravel layer. Soils developed under long-term grass, even when disturbed and restored to grass will retain much of their original structure. Therefore, although not measured in this study, water infiltration in the $\mathrm{NH}$ plots does not appear to be appreciably affected.

Table 3. Effects of management on profile changes in soil inorganic carbon levels over a five year period for undisturbed native grassland, undisturbed native grassland that was tilled and restored to grassland and long-term cropland converted to grass.

\begin{tabular}{|c|c|c|c|c|c|c|c|c|}
\hline \multirow[t]{3}{*}{ Depth Increment } & \multicolumn{8}{|c|}{ Grazing Management } \\
\hline & \multicolumn{4}{|c|}{ Ungrazed (UG) } & \multicolumn{4}{|c|}{ Grazed (GG) } \\
\hline & 1999 & 2004 & $\begin{array}{c}\text { Total } \\
\text { Change }\end{array}$ & $\begin{array}{l}\text { Annual } \\
\text { Change }\end{array}$ & 1999 & 2004 & $\begin{array}{c}\text { Total } \\
\text { Change }\end{array}$ & $\begin{array}{l}\text { Annual } \\
\text { Change }\end{array}$ \\
\hline \multirow[t]{2}{*}{$\mathbf{c m}$} & \multicolumn{4}{|c|}{$\mathrm{kg} \cdot \mathrm{m}^{-2}$} & \multicolumn{4}{|c|}{$\mathrm{kg} \cdot \mathrm{m}^{-2}$} \\
\hline & \multicolumn{8}{|c|}{ Undisturbed native grassland (NH Control) } \\
\hline $0-10$ & 0.00 & 0.00 & 0.00 & 0.00 & & & & \\
\hline $10-20$ & 0.00 & 0.00 & 0.00 & 0.00 & & & & \\
\hline $20-30$ & 0.05 & 0.00 & -0.05 & -0.01 & & & & \\
\hline $30-45$ & 0.00 & 0.25 & 0.25 & 0.05 & & & & \\
\hline $45-60$ & 0.38 & 0.75 & 0.37 & 0.07 & & & & \\
\hline \multirow[t]{2}{*}{ Total } & 0.44 & 1.00 & 0.56 & 0.11 & & & & \\
\hline & \multicolumn{8}{|c|}{ Undisturbed native grassland with tillage and restoration to grass $(\mathrm{NH})$} \\
\hline $0-10$ & 0.00 & 0.00 & 0.00 & 0.00 & 0.00 & 0.00 & 0.00 & 0.00 \\
\hline $10-20$ & 0.00 & 0.00 & 0.00 & 0.00 & 0.00 & 0.00 & 0.00 & 0.00 \\
\hline $20-30$ & 0.31 & 0.00 & -0.31 & -0.06 & 0.00 & 0.00 & 0.00 & 0.00 \\
\hline $30-45$ & 0.03 & 0.11 & 0.08 & 0.02 & 0.00 & 0.22 & 0.22 & 0.04 \\
\hline $45-60$ & 0.03 & 0.78 & 0.76 & 0.15 & 0.00 & 0.63 & 0.63 & 0.13 \\
\hline \multirow[t]{2}{*}{ Total } & 0.36 & 0.89 & 0.53 & 0.11 & 0.00 & 0.85 & 0.85 & 0.17 \\
\hline & \multicolumn{8}{|c|}{ Cropland restored to grassland $(\mathrm{CH})$} \\
\hline $0-10$ & 0.00 & 0.00 & 0.00 & 0.00 & 0.05 & 0.00 & -0.05 & -0.01 \\
\hline $10-20$ & 0.00 & 0.00 & 0.00 & 0.00 & 0.11 & 0.00 & -0.11 & -0.02 \\
\hline $20-30$ & 0.00 & 0.07 & 0.07 & 0.01 & 0.00 & 0.00 & 0.00 & 0.00 \\
\hline $30-45$ & 0.00 & 0.08 & 0.08 & 0.02 & 0.00 & 0.00 & 0.00 & 0.00 \\
\hline $45-60$ & 1.49 & 0.00 & -1.49 & -0.30 & 1.38 & 0.54 & -0.84 & -0.17 \\
\hline Total & 1.49 & 0.15 & -1.34 & -0.27 & 1.54 & 0.54 & -1.00 & -0.20 \\
\hline
\end{tabular}

\subsection{Soil Total Carbon}

Changes in soil total carbon (STC) for the five treatments between 1999 and 2004 are shown in Table 4. The greatest change in STC was observed for the undisturbed native grass. The NH area that had been tilled and is restored to grass showed STC values of $54 \%$ and $98 \%$ of the undisturbed grass with and without grazing, respectively. The $\mathrm{CH}$ area restored to grass showed an STC accumulation of $20 \%$ of the undisturbed grass with grazing. The large decrease in STC in the $45-60 \mathrm{~cm}$ depth zone of the grass established on long-term cropland reflects the large change in SIC as previously described above.

As STC is the sum of the SOC and SIC, it represents the total change in soil C due to changes in land and soil management. The increase or decrease in total carbon may be due to a lag in the response of nutrient availability for growing plants to changes in soil management [36]. Tillage increases SOM decomposition in the soil thereby decreasing total $\mathrm{C}$ but increases the availability of nutrients originally contained in the SOM. In this study, the SOM increased over the five years which supports the findings of Burke et al. [36]. Increase in residue inputs due to decreased tillage thereby decreases SOM decomposition [37-41]. The decrease in total carbon in the $45-60 \mathrm{~cm}$ depth of the soil profile 
appears to be due to a decrease in SIC in this depth layer related more to water movement in the soil system than changes in potential nutrient availability.

Table 4. Effects of management on profile changes in soil total carbon levels over a five year period for undisturbed native grassland that was tilled and restored to grassland and cropland converted to grass.

\begin{tabular}{|c|c|c|c|c|c|c|c|c|}
\hline \multirow[t]{3}{*}{ Depth Increment } & \multicolumn{8}{|c|}{ Grazing Management } \\
\hline & \multicolumn{4}{|c|}{ Ungrazed (UG) } & \multicolumn{4}{|c|}{ Grazed (GG) } \\
\hline & 1999 & 2004 & $\begin{array}{c}\text { Total } \\
\text { Change }\end{array}$ & $\begin{array}{l}\text { Annual } \\
\text { Change }\end{array}$ & 1999 & 2004 & $\begin{array}{c}\text { Total } \\
\text { Change }\end{array}$ & $\begin{array}{l}\text { Annual } \\
\text { Change }\end{array}$ \\
\hline \multirow[t]{2}{*}{$\mathrm{cm}$} & \multicolumn{4}{|c|}{$\mathrm{kg} \cdot \mathrm{m}^{-2}$} & \multicolumn{4}{|c|}{$\mathrm{kg} \cdot \mathrm{m}^{-2}$} \\
\hline & \multicolumn{8}{|c|}{ Undisturbed native grassland (NH Control) } \\
\hline $0-10$ & 2.28 & 3.09 & 0.81 & 0.16 & & & & \\
\hline $10-20$ & 1.55 & 1.86 & 0.31 & 0.06 & & & & \\
\hline $20-30$ & 1.09 & 1.41 & 0.32 & 0.06 & & & & \\
\hline $30-45$ & 1.32 & 2.43 & 1.10 & 0.22 & & & & \\
\hline $45-60$ & 1.89 & 3.25 & 1.36 & 0.27 & & & & \\
\hline \multirow[t]{2}{*}{ Total } & 8.13 & 12.04 & 3.90 & 0.78 & & & & \\
\hline & \multicolumn{8}{|c|}{ Undisturbed native grassland with tillage and restored to grass (NH) } \\
\hline $0-10$ & 2.43 & 2.85 & 0.41 & 0.08 & 2.81 & 2.83 & 0.02 & 0.00 \\
\hline $10-20$ & 1.29 & 2.06 & 0.77 & 0.15 & 1.35 & 1.72 & 0.36 & 0.07 \\
\hline $20-30$ & 1.27 & 1.35 & 0.08 & 0.02 & 1.15 & 1.22 & 0.06 & 0.01 \\
\hline $30-45$ & 1.13 & 2.11 & 0.98 & 0.20 & 1.52 & 2.07 & 0.55 & 0.11 \\
\hline $45-60$ & 0.98 & 2.54 & 1.56 & 0.31 & 1.34 & 2.45 & 1.11 & 0.22 \\
\hline \multirow[t]{2}{*}{ Total } & 7.11 & 10.90 & 3.80 & 0.76 & 8.17 & 10.28 & 2.11 & 0.42 \\
\hline & \multicolumn{8}{|c|}{ Cropland restored to grassland $(\mathrm{CH})$} \\
\hline 0-10 & 1.56 & 1.77 & 0.21 & 0.04 & 1.58 & 1.91 & 0.33 & 0.07 \\
\hline $10-20$ & 1.23 & 1.76 & 0.52 & 0.10 & 1.55 & 1.77 & 0.21 & 0.04 \\
\hline $20-30$ & 0.99 & 1.39 & 0.40 & 0.08 & 0.88 & 1.21 & 0.33 & 0.07 \\
\hline $30-45$ & 1.42 & 1.79 & 0.37 & 0.07 & 1.66 & 1.96 & 0.30 & 0.06 \\
\hline $45-60$ & 3.23 & 2.51 & -0.72 & -0.14 & 3.49 & 2.88 & -0.61 & -0.12 \\
\hline Total & 8.44 & 9.22 & 0.78 & 0.16 & 9.16 & 9.72 & 0.56 & 0.11 \\
\hline
\end{tabular}

\section{Summary and Conclusions}

Soils within the Great Plains generally have high natural fertility and good water-holding capacity. The surface soil layer tends to posses increasing amounts of organic matter as precipitation increases while large amounts of precipitated calcium are present at lower depths in the lower rainfall areas [7]. Rangeland ecosystems are very complex and are highly variable with a wide range of $C$ accumulation levels found from one grassland to the next as well as on differing slopes, landscape positions, and aspects. The type of soil and climate also play an important role in sequestration. Finally, soil C accumulation is affected by soil disturbance. Since rangeland soils are not normally tilled or mechanically disturbed, the $C$ sequestration potential in these soils is very high. Grazing effects are minimal when compared to tilled systems because of low soil disturbance of the near-surface soil mass. Because of the low soil disturbance and a high concentration of fibrous root systems in grassland soils, they can be efficient sinks for carbon.

Former croplands converted to grassland have a high capacity to sequester SOC because of decreased soil disturbance as well as generally low SOC. This study shows that SOC increases in soils converted from cultivated land to grassland but the increase may not be as high as for grassland that has been disturbed and quickly restored to grass. Although not evaluated in this study, but based on the apparent movement of SIC into underlying soil layers, soil disturbance in grasslands may influence water movement through the soil profile across several growing seasons after the disturbance occurs. 
When grasslands are grazed shortly after they have been restored, animal hoof action may destroy existing soil aggregates before grass root systems are fully established. Reduced soil aggregation, even due to minor soil disturbance (hoof action), may result in the release of some $\mathrm{CO}_{2}$ back to the atmosphere, thereby reducing net $C$ sequestration. In addition, poor soil structure may reduce plant growth which, in turn, also reduces the rate of $C$ sequestration. From the data collected in this study from the GG versus the UG restored grassland, soil aggregate formation as well as internal soil water relationships within the soil profile may be related to increased $C$ accumulation. However, since soil aggregate data was not collected in this study, further research may be required to confirm this observation.

Soil inorganic $\mathrm{C}$ in the $\mathrm{CH}$ area shows a decrease in the $45-60 \mathrm{~cm}$ zone. When the soil is managed as cropland, soil bulk density is higher than when managed as long-term grassland [2]. Under UG, structure develops, reducing soil bulk density and can result in improved water movement through the soil profile. When cropland is converted to grassland, greater structure and lower bulk density can occur which can lead to improved water movement through the soil resulting in inherent SIC to dissolve and move deeper into the profile. Even under a semi-arid climate, increased water infiltration can cause enhanced carbonate dissolution and leaching.

Most grass species are highly colonized with mycorrhizae specific to the grass species present [32]. When native grassland is disturbed and immediately restored to grass species, a high inoculum of mycorrhizae is already present to infect the reestablished grasses. However, under long-term cropland management $(\mathrm{CH})$, an inoculum of grassland specific mycorrhizae is absent. Thus, higher $\mathrm{C}$ sequestration rates were observed in the grass management treatments in the $\mathrm{NH}$ plots than in the $\mathrm{CH}$ plots.

Examining total soil $\mathrm{C}$ provides insight into the type of soil changes that occur when changes are imposed on crop and land management. The changes reflect the sum of the changes in SOC and SIC with soil and land management changes as they influence the STC with the accumulation of $C$ in the soil. The ranking of the treatments in this study relative to the total amounts of $C$ accumulated in the surface $60 \mathrm{~cm}$ zone of the soil (Native > NHUG > NHGG > CHUG > CHGG) provides an insight into soil processes (soil aggregation, water relations, and movement) that influence soil $\mathrm{C}$ accumulation and ultimately sequestration.

This study illustrates that further research is needed to further elucidate the changes in the soil environment that occur when soil and land management changes are imposed. However, it is evident from this study that management changes impact the deeper soil profile depths which influence the "total" capacity of soils to sequester C. When studying sequestered soil C, researchers often assume that $\mathrm{C}$ accumulated below the soil surface becomes permanent and protected (i.e., immobile) from loss back to the atmosphere. This study shows that soil systems may also lose $C$ due to mobility to depths in the soil beneath the layers that can be sampled in a practical way providing additional insight into the behavior of $C$ in soil systems.

Author Contributions: Conceptualization, T.F., G.Y., and L.C.; site management, T.F. and C.S.; methodology, G.Y. and L.C.; sampling, G.Y. and L.C.; formal analysis, G.Y. and L.C.; writing-original draft preparation, G.Y. and L.C.; writing - review and editing, G.Y. and L.C.; project administration, L.C., T.F., and C.S.; funding acquisition, L.C. and T.F. All authors have read and agreed to the published version of the manuscript.

Funding: This research was partly supported by NDSU Hatch Project No. FARG008572 of the National Institute of Food and Agriculture, U.S. Department of Agriculture and the U.S. Department of Energy, Grant No. DE-FC-26-03NT41982 (Plains $\mathrm{CO}_{2}$ Reduction Partnership $\left(\mathrm{PCO}_{2} \mathrm{R}\right)$ ) through the University of North Dakota, Energy and Environment Research Center.

Acknowledgments: The authors gratefully acknowledge the initial ideas for this study by various individuals in the NDSU Animal Science and Ag Economics Departments, Lynn Foss and Lynette De Silva with assistance for soil sampling, Frank Higgins and numerous undergraduate students for assistance with soil sample processing, and Keith Jacobson with OC and IC analysis.

Conflicts of Interest: The authors declare no conflict of interest. The funders had no role in the design of the study, in the collection, analysis, or interpretation of data; in the manuscript, and the decision to publish the results. 


\section{Abbreviations}

$\begin{array}{ll}\text { CH } & \text { cropped history } \\ \text { NH } & \text { native grassland history } \\ \text { GG } & \text { grazed grass } \\ \text { UG } & \text { ungrazed grass } \\ \text { TC } & \text { total carbon } \\ \text { IC } & \text { inorganic carbon } \\ \text { OC } & \text { organic carbon } \\ \text { SOC } & \text { soil organic carbon } \\ \text { SIC } & \text { soil inorganic carbon } \\ \text { STC } & \text { soil total carbon }\end{array}$

\section{References}

1. Lal, R.; Follett, R.F.; Kimble, J.M. Achieving soil carbon sequestration in the United States: A challenge to the policy makers. Soil Sci. 2003, 168, 827-845. [CrossRef]

2. Cihacek, L.J.; Ulmer, M.G. Estimated soil organic carbon losses from long-term crop-fallow in the northern Great Plains of the USA. In Soil Management and Greenhouse Effect; Lal, R., Kimble, J.M., Levine, E., Stewart, B.A., Eds.; Lewis Publishers: Boca Raton, FL, USA, 1995; pp. 72-85.

3. Mann, L.K. Change in soil C storage after cultivation. Soil Sci. 1986, 142, 279-288. [CrossRef]

4. Davidson, R.L. Root systems-the forgotten component of pastures. In Plant Relations in Pastures; Wilson, J.R., Ed.; CSIRO: East Melbourne, Australia, 1978; pp. 86-94.

5. Houghton, R.A.; Hobbie, J.E.; Melillo, J.M.; Moore, B.; Peterson, B.J.; Shaver, G.R.; Woodwell, G.M. Changes in the carbon content of terrestrial biota and soils between 1860 and 1980. A net release of carbon dioxide to the atmosphere. Ecol. Monogr. 1983, 53, 235-262. [CrossRef]

6. Follett, R.F.; Kimble, J.M.; Lal, R. (Eds.) The Potential of U.S. Grazing Lands to Sequester Carbon and Mitigate the Greenhouse Effect; Lewis Publishers: Boca Raton, FL, USA, 2001.

7. Liebig, M.A.; Morgan, J.A.; Reeder, J.D.; Ellert, B.H.; Gollany, H.T.; Schuman, G.E. Greenhouse gas contributions and mitigation potential of agricultural practices in northwestern USA and western Canada. Soil Till. Res. 2005, 83, 25-52. [CrossRef]

8. Donigian, A.S., Jr.; Barnwell, T.O.; Kackson, R.B.; Parwardhan, A.S.; Weomreocj, K.B.; Rowell, A.L.; Chinnaswamy, R.V.; Cole, C.V. Assessment of Alternative Management Practices and Policies Affecting Soil Carbon in Agroecosystems of the Central United States; Publ. No. EPA/600/R-94/067; US-EPA: Washington, DC, USA, $1994 ; 362 \mathrm{p}$.

9. Janzen, H.H.; Campbell, C.A.; Izaurralde, R.C.; Ellert, B.H.; Juma, N.; McGill, W.B.; Zentner, R.P. Management effects on soil C storage on the Canadian prairies. Soil Till. Res. 1998, 47, 181-195. [CrossRef]

10. VandenBygaart, A.J.; Gregorich, E.G.; Angers, D.A. Influence of agricultural management on soil organic carbon: A compendium and assessment of Canadian studies. Can. J. Soil Sci. 2003, 83, 363-380. [CrossRef]

11. Cihacek, L.J.; Ulmer, M.G. Effects of tillage on profile soil carbon distribution in the northern Great Plains of the U.S. In Management of Carbon Sequestration in Soil; Lal, R., Kimble, J.M., Levine, E., Stewart, B.A., Eds.; CRC Press: Boca Raton, FL, USA, 1997; pp. 83-91.

12. Cihacek, L.J.; Ulmer, M.G. Effects of tillage on inorganic carbon storage in soils of the northern great plains of the U.S. In Management of Carbon Sequestration in Soil; Lal, R., Kimble, J.M., Follett, R.F., Stewart, B.A., Eds.; CRC Press: Boca Raton, FL, USA, 2002; pp. 63-69.

13. Elena, M.; Christopher, P.; Larry, C.; Michael, U. Soil inorganic carbon sequestration as a result of cultivation in the Mollisols. In Carbon Sequestration and It's Role in the Global Carbon Cycle; McPherson, B.J., Sundquist, E.T., Eds.; Geophysical Monograph Series; John Wiley \& Sons: Washington, DC, USA, 2009; Volume 183, pp. 129-133.

14. Schuman, G.E.; Janzen, H.H.; Herrick, J.E. Soil carbon dynamics and potential carbon sequestration by rangelands. Environ. Poll. 2002, 116, 391-396. [CrossRef]

15. Bruce, J.P.; Frome, M.; Haites, H.; Janzen, H.; Lal, R.; Paustian, K. Carbon sequestration in soils. J. Soil Water Conserv. 1999, 54, 382-389. 
16. Conant, R.T.; Paustian, K.; Elliott, E.T. Grassland management and conservation into grassland: Effects on soil carbon. Ecol. Appl. 2001, 11,343-355. [CrossRef]

17. Polley, H.W.; Morgan, J.A.; Campbell, B.D.; Stanfford, M.S. Crop ecosystem responses to climatic change: Rangelands. In Climate Change and Global Crop Productivity; Reddy, K.R., Hodges, H.F., Eds.; CABI Publishing: Wallingford, UK, 2000; pp. 293-314.

18. Gebhart, D.L.; Johnson, H.B.; Mayeux, H.S.; Polley, H.W. The CRP increases soil organic carbon. J. Soil. Water. Cons. 1994, 49, 488-492.

19. Burke, I.C.; Lauenroth, W.K.; Coffin, D.P. Soil organic matter recovery in semiarid grasslands: Implications for the conservation Reserve Program. Ecol. Appl. 1995, 5, 793-801. [CrossRef]

20. Elbersen, G.W.W.; Davies, G.R.; van Reeuwijk, L.P.; Janssen, R.P.T. Quantification of the incorporation of atmospheric CO2 in calcic horizons. In Global Climate Change, Pedogenic Carbonates; Lal, R., Kimble, J.M., Eswaran, H., Stewart, B.A., Eds.; Lewis Publishers: Boca Raton, FL, USA, 2000; pp. 87-95.

21. Reeder, J.D.; Franks, C.D.; Milchunas, D.G. Root biomass and microbial processes. In The Potential of U.S. Grazing Lands to Sequester Carbon and Mitigate the Greenhouse Effect; Follett, R.F., Kimble, J.M., Lal, R., Eds.; Lewis Publishers: Boca Raton, FL, USA, 2001; pp. 139-166.

22. Reeder, J.D.; Schuman, G.E.; Morgan, J.A.; LeCain, D.R. Response of organic and inorganic carbon and nitrogen to long-term grazing of the short grass steppe. Environ. Manag. 2004, 33, 485-495. [CrossRef] [PubMed]

23. Mihailova, E.A.; Post, C.J. Effects of land use on soil inorganic carbon stocks in the Russian Chernozem. J. Environ. Qual. 2006, 35, 1384-1388. [CrossRef] [PubMed]

24. North Dakota Agricultural Weather Network (NDAWN). 2020. Available online: https//ndawn.ndsu.edu. nodak.edu/station-info.html?station=29 (accessed on 8 June 2020).

25. USDA-SCS (U.S. Department of Agriculture Soil Conservation Service). Land resource regions and major land resource areas of the United States. In Agriculture Handbook 296; U.S. Government Printing Office: Washington, DC, USA, 1981; 156p.

26. USDA-NRCS (U.S. Department of Agriculture Natural Resource Conservation Service). Official Series Description-Bowdle Series. 1999. Available online: https://soilseries.sc.egov.usda.gov/OSD_Docs/B/Bowdle. hmtl (accessed on 30 May 2020).

27. USDA-NRCS (U.S. Department of Agriculture Natural Resource Conservation Service). Official Series Description-Ruso Series. 1999. Available online: https://soilseries.sc.egov.usda.gov/OSD_Docs/R/Ruso.hmtl (accessed on 30 May 2020).

28. Yellajosula, G. Soil C Sequestration in the Northern Great Plains. Ph.D. Thesis, North Dakota State University, Fargo, ND, USA, 2010; 347p.

29. Blake, G.R.; Hartge, K.H. Bulk density. In Methods of Soil Analysis. Part 1, 2nd ed.; Klute, A., Ed.; Agron. Monogr. 9; ASA and SSSA: Madison, WI, USA, 1986; pp. 363-375.

30. Cihacek, L.J.; Jacobson, K.A. Effects of soil sample grinding intensity on carbon determination by high-temperature combustion. Comm. Soil. Sci. Plant Anal. 2007, 38, 1733-1739. [CrossRef]

31. SAS Institute Inc. SAS Version 9.1.3; SAS Campus Drive: Cary, NC, USA, 2002.

32. Bingham, M.A.; Biondini, M. Mycorrhyzial hyphal length as a function of plant community richness and composition in restored northern tallgrass prairie (USA). Rangel. Ecol. Manag. 2009, 62, 60-67. [CrossRef]

33. Middleton, E.L.; Bever, J.D. Inoculation with a native soil community advances succession in a grassland restoration. Rest. Ecol. 2010, 20, 218-226. [CrossRef]

34. Schuster, J.L. Root development of native plants under three grazing intensities. Ecol. Soc. Am. 1964, 45, 63-70. [CrossRef]

35. Holland, E.A.; Detling, J.K. Plant response to herbivory and belowground nitrogen cycling. Ecology 1990, 71 , 1040-1049. [CrossRef]

36. Burke, I.C.; Elliott, E.T.; Cole, C.V. Influence of macro climate, landscape position, and management on organic matter in agroecosystems. Ecol. Appl. 1995, 5, 124-131. [CrossRef]

37. Doran, J.W. Microbial changes associated with residue management with reduced tillage. Soil Sci. Soc. Am. J. 1980, 44, 518-524. [CrossRef]

38. Doran, J.W. Soil microbial biochemical changes associated with reduced tillage. Soil Sci. Soc. Am. J. 1980, 44, 765-771. [CrossRef]

39. Rice, C.W.; Smith, M.S. Short-term immobilization of fertilizer nitrogen at the surface of no-till and plowed soils. Soil. Sci. Soc. Am. J. 1984, 48, 295-297. [CrossRef] 
40. Wood, C.M.; Westfall, D.G.; Peterson, G.A.; Birke, I.C. Impacts of cropping intensity on carbon and nitrogen mineralization under no-till dryland agroecosystems. Agron. J. 1990, 82, 1115-1120. [CrossRef]

41. Wood, C.W.; Westfall, D.G.; Peterson, G.A. Soil carbon and nitrogen changes on initiation of no-till cropping systems. Soil Sci. Soc. Am. J. 1991, 55, 470-476. [CrossRef]

(C) 2020 by the authors. Licensee MDPI, Basel, Switzerland. This article is an open access article distributed under the terms and conditions of the Creative Commons Attribution (CC BY) license (http://creativecommons.org/licenses/by/4.0/). 